\title{
Improving Students' Listening Comprehension through New Vocabulary Learning
}

\section{Christian Neni Purba}

English Department, Nommensen HKBP University, Indonesia cristian.purba@uhn.ac.id

\begin{abstract}
This research is about the improving student's comprehension in listening through introducing the new vocabulary. The background of research was based on phenomenon that students had in the classroom at FKIP UHN. They had problems in listening one of the them was lack of vocabulary. This research focused on the way to improve the students' comprehension in listening.This research applies classroom action research, aimed to describe the improvement process of teaching learning listening. $t$ used intimate language style. The result of this study found that in the pre cycle the students' average score is $57.82 \%$. In the first cycle the students' average score is 68.38. In the second cycle the students' average score is 72 . The average of students score was always increasing. It means that improvement of students listening comprehension increase each cyles by learning new vocabulary.
\end{abstract}

\section{Keywords}

Listening comprehension; improving; vocabulary

\section{Introduction}

The aim of teaching listening is to raise the students' listening skill. Increasing the students' comprehension and the awareness of the nature and importance of English, improving their competitiveness in the global society is the essential goal of listening. The English teaching and learning processis also aimed at developing the students' understanding of the relationship between language and culture.

Global communication relies heavily on English language skills because English has become a means to access valuable information and resources delivered through various media, both print and electronic media in accordance with SDGs and MDGs found in Education for Sustainable Development (ESD) (Hermann in Syakur, 2020). This is a response from the Issues of Global Challenges through Character Education and National Insight

Most of the students are not able to write what they have heard. They even fail tofind the main idea and also some supporting ideas or details from the audio. They do not understand clearly the message of speaker, because there are some new vocabularies. The topic is not familiar even something new for them. Finally the students face difficulties in answering the questions. On the other side, most of the students do not practice listening regularly at home, listening kinds of English audio that spoken by native speakers. The writer also finds that the students have a problem how to spell new words.

There are some problems found, especially in the teaching of the listening skill. Those problems are divided into two main problems, internal and external. The internal problem is the basic problem that is always found in thelistening skill. The students are not able to understand the whole of sentences in there cording. The second problem is colloquial language. The students miss to recognize the meaning of words because limitation of bank words, so they do not understand what words spoken by the speakers that make them bored 
and frustrated. Listeners cannot control the speed of the native speaker who conveys the message. The listeners have no time to repeat or clarify the message conveyed. They are not able to concentrate because of various thing; unattractive topics, physical conditions, noisy environment.

\section{Review of Literature}

\subsection{Listening}

Listening is one of the subjects studied in the field of language study and in the discipline of conversation analysis. This skill can be improved by practice and there are many rewards to develop your listening skill. It is the active process of receiving and responding to spoken (and sometimes unspoken) messages. Helgesen (2003:24) states that listening is an active, purposeful process of making sense of what we hear. More often we hear, more we can understand something. Regarding that citation, although listening is receptive, it is very active because listeners can think and understand things at higher levels than what they have heard. As they listen, they process not only what they hear but also connect it with other information they have already known. Since listeners combine what they have listened to their existing knowledge and experiences, they are figuring or creating some kinds of meaning in their own mind. Rost (2002:177) defines listening, in its broadest sense, as a process of receiving what the speaker actually says (receptive orientation); constructing and representing meaning (constructive orientation); negotiating meaning with the speaker and responding (collaborative orientation); and, creating meaning through involvement, imagination and empathy (transformative orientation). Listening, then, is a complex, active processes of interpretation in which listeners match what they hear with what they have already known. The characteristics of thematic learning as revealed by the Ministry of National Education (2006) are: (1) learning experiences and activities are very relevant to the level of development and needs of students, (2) the activities chosen in the implementation of thematic learning are based on students' interests and needs, (3) learning activities will be more meaningful and memorable for students so that learning outcomes can last longer, (4) help develop students' thinking skills, (5) present pragmatic learning activities in accordance with problems that are often encountered by students in their environment, and (6) develop students' social skills, such as cooperation, tolerance, communication, and responsiveness to the ideas of others.

Listening is an active process of interpretation, listeners match what they have heard with what they have already known and been understood. It is a process to start mind. We must pay attention first to listening skills then the students can easily study the other skills.

\subsection{Teaching Listening}

Brown (2000:7) says that teaching is showing or helping someone to learn how to do something, giving instructions, guiding in the study of something, providing with knowledge, causing to know or understand. Listening has also been considered from a further perspective in recent years when it is examined in relation not only to comprehension, but also to language learning. Teaching listening requires a bit more on the part of the teacher than that of the learners.

The importance of listening in language learning and teaching demand thelanguage teachers to help their students become effective listeners. (Maria, 1998), for instance, the school establishes one day in a week to use English language, so the students will be familiar with listening process. There are some principles of teaching listening skill that should be 
known by the teacher (Brown, 2007). First, listening should receive primary attention inthe early stage of ESL instruction. It means that to learn English language, students should be familiar first with the listening process. Second, listening should maximize the use of material that is relevant to students' real life. It can make students know how important the material in the real life. Third, listening should maximize the use of authentic language, because students are difficult to understand if the teacher uses difficult word. Fourth, listening should vary the materials in terms of speakers' gender, age, dialect, accent, topic, speed, noise, level, and genre. The purpose of that principle is to make the students interested in the material given in every meeting. Fifth, the teacher should always ask the students to listen to the purposes of listening and ask them to show their comprehension in a task. It can drill their listening skill. Sixth, the language material intended to be used for training listening comprehension should never be resented visually first. The students have to be familiar with the audio first. Furthermore, the teachers have to pay attention to the principles in teaching listening. As mentioned above, one of the principles in teaching listening is that the teacher always asks the students to listen to the purposes of listening.

\subsection{Listening Comprehension}

Listening comprehension is the traditional way of thinking about the nature of listening. Indeed, in most methodology manuals listening and listening comprehension are synonymous. This view of listening is based on the assumption that the basic function of listening in second language learning is to facilitate understanding of spoken discourse. We will examine this view of listening in some detail before considering a complementary view of listening as acquisition. This latter view of listening considers how listening can provide input that triggers the further development of second-language proficiency. Clearly, the general purpose of listening is to comprehend a message. Since the listener has to understand the message as it is presented, effective listening requires the ability to organize and remember what is presented. Listening then involves giving conscious attention to the sounds for the purpose of gaining meaning. The message must be given adequate attention, or concentration, so that it can supersede all other competing sounds and be comprehended. There are different kinds of comprehension. According to Lund (1990) he categorized comprehension into main-idea comprehension, detail comprehension, and full comprehension. Main-idea comprehension involves actual comprehension of the messages and depends primarily on recognition of vocabulary. Detail comprehension involves getting specific information; it may be performed independently of main-idea comprehension when listeners know in advance what information they are listening for. Full comprehension, which is the goal of listening instruction, involves understanding the whole message--the main ideas and the details. Comprehension does not always require understanding every word or structure. Students usually assume that successful comprehension only occurs with total comprehension. Students become frightened when they fail to understand every single word they hear. Indeed, teachers should help their students understand that it is not necessary to recognize and understand every word in order to function well in listening comprehension.

\subsection{Vocabulary}

Vocabulary is a list of words in English with different meaning and function that people use to refer to an object and to make a sentence. Vocabulary is the very basic thing about English that people should learn at first. This is because vocabulary is needed when we want to say or pointing at something. "Vocabulary is a language central and of critical importance of typical language" (Nilawati, 2009:8). She explained that vocabulary is very important because it's being used in people's communication and be used as a basic foundation to 
construct some words into a good sentence. Without mastering vocabulary, people can't communicate effectively or even expressing their ideas.

Introducing vocabularies involves some steps (Lado, 1964:121) the students hear the sounds from their teacher as the first model of a good pronunciation. Teacher pronounces the sound many times and the students repeat it several times. Repetition has important rule in pronunciation. The students has chance to pronounce new vocabularies. After the teacher give the correct pronunciations of new words the students should practice them several times. This way will help the student to remember the sound in longer period of time. Teacher should correct the student in pronouncing the sounds. The last steps the students should be able to predict the meaning of unfamiliar words. Teacher gives indirect definition of words.

\subsection{Principle of Vocabulary Teaching in Listening}

The important part in language learning is vocabulary. Teacher should apply some principles of learning vocabulary. They are:

1. Focus on the most useful vocabulary

Vocabulary selection by teacher needed to rely on the most useful vocabulary in order to meet the needs of various goals and situations. It means that the vocabulary or the material must be allocated properly to the lesson.

2. Focus on the vocabulary in the most appropriate way

The words taught and learned by the students in an appropriate way. Teacher sees the most suitable way in teaching vocabulary from the high frequency words to the tow frequency.

3. Give attention to the high frequency words across the four strands of course.

High frequently world should be given fully attention and become priority to be taught, since they are mostly appear in listening, writing, speaking, reading also they are related to receptive and productive use.

4. Encourage learners to reflect on and take responsibility for learning

Students should be able to take responsibility in learning vocabulary process; knowledge of what to learn and the range of learning vocabulary, skill choosing the best options, and the ability to monitor and evaluate progress with those options. The students are the only one who takes responsibility to learn and to carry on learning in teaching learning process.

\subsection{Conceptual Framework}

Listening is perhaps the most critical element in language and languagelearning, for it is the key to speaking, and beyond that, reading and writing.Particularly in the workplace, that skill is used at least three times more than speaking, and four to five times more than reading and writing. Listening and speaking are often taught together, but beginners, especially non-literate ones, should be given more listening practice than speaking practice. Listening skill is a complex active skill of interpretation in which listeners matches what they hear and what they have already known. Vocabulary takes big part in listening comprehension.

\section{Research Method}

The research conducted in the second semester of the academic year 2018/19. The observation conducted in March 9th, 2019. The research was held in April to June 2019. The study took placeaccording to the class schedule in which the English subject was taught once a week. The duration was 100 minutes for each meeting (two credits). 
The data were collected in the form of qualitative and quantitative data. The qualitative data were obtained by interviewing the students, doingobservation during the teachinglearning process and the implementation of the action in the field.

Meanwhile, the quantitative data were in the form of students' listening scores. The scores were collected through the listening assessments which conducted once in this study. The first was pre-test. It was conducted to know the students' listening proficiency. The second was post-test. It was done to know whether there was improvement of the students' listening skill. There were three kinds of technique used by the researcher to collect the data.They were interview, test and observation. Each technique was also followed by the instruments.

\section{Discussion}

Based on the observation result teaching listening was still low. The average score of students. The score of the observation as below:

$$
\begin{aligned}
\text { Score } & =\frac{\text { Total score }}{\text { Maximal score }} \times 100 \% \\
& =\frac{38}{55} \times 100 \% \\
& =69.01 \%
\end{aligned}
$$

Based on the observation checklist above it was resulted that teacher's performance in listening skill was only $69.01 \%$ or can be called "good" criteria. The score could reach from $60 \%-80 \%$. The lecturer still needed to have some ways in teaching listening in order to improve students' performances. Here, lecturer should be creative if she wanted to improve his teaching quality. It should be done since lecturer's teaching performances were crucial in affecting students' motivation and performance in learning process. From the result of observation checklist above it concluded that many of the students joined the class was enthusiastically.

It was followed by 34 students and the teacher provided 60 minutes for them to do the test. The result of pre-cycle test seen in the table below:

Table 1. Result of the Pre Cycle Test

\begin{tabular}{|c|c|}
\hline Initial students' Name & Score \\
\hline DA & 58 \\
\hline MYA & 58 \\
\hline Y L G & 46 \\
\hline LS & 56 \\
\hline AWN & 76 \\
\hline ERN & 64 \\
\hline OS & 84 \\
\hline AMS & 60 \\
\hline NAKN & 40 \\
\hline ND & 42 \\
\hline
\end{tabular}




\begin{tabular}{|c|c|}
\hline M & 66 \\
\hline USI & 82 \\
\hline SRFP & 60 \\
\hline ET & 48 \\
\hline YS & 66 \\
\hline PGS & 44 \\
\hline NLP & 64 \\
\hline EPS & 60 \\
\hline MRT & 54 \\
\hline YS & 56 \\
\hline YES & 50 \\
\hline PDSM & 60 \\
\hline RYS & 66 \\
\hline FS & 58 \\
\hline ASD & 60 \\
\hline NMA & 66 \\
\hline MS & 50 \\
\hline MYS & 60 \\
\hline MS & 48 \\
\hline RYS & 48 \\
\hline ALH & 58 \\
\hline SMH & 60 \\
\hline DWS & 48 \\
\hline WCN & 50 \\
\hline TOTAL & 1966 \\
\hline
\end{tabular}

After calculating the students score, the researcher calculated the mean to measure the improvement of students' score in every cycle. To know the mean of the students' score in the pre cycle the researcher used formula as follows:

$$
\mathrm{X}=\frac{1966}{34} \times 100 \%
$$

\section{$X=57.82$}

From the data above, it showed that the average of the students score in the pre cycle is 57.82. This score is on level scoring " $\mathrm{C}+$ ". The score of $\mathrm{C}+$ is 55-58.9 points. The teacher lecturer decided to use another technique to make students interested in the learning process in order to improve students' ability in listening skills. She decided introducing the vocabulary to improve their ability in listening skills.

The result of research shows that there was significant improvement of students' ability in listening introducing vocabularies. It can be seen from the result of the test from the first cycle until third cycle. They can be shown below: 
Table 2 Result Test the Cycles

\begin{tabular}{|c|c|c|c|}
\hline Initial students' Name & $\begin{array}{c}\text { Score Pre } \\
\text { Cycle }\end{array}$ & $\begin{array}{c}\text { Score First } \\
\text { Cycle }\end{array}$ & $\begin{array}{c}\text { Score of Second } \\
\text { Cycle }\end{array}$ \\
\hline DA & 58 & 80 & 79 \\
\hline MYA & 58 & 71 & 76 \\
\hline YLG & 46 & 55 & 66 \\
\hline LS & 56 & 61 & 71 \\
\hline AWN & 76 & 81 & 79 \\
\hline ERN & 6 & 70 & 68 \\
\hline OS & 84 & 86 & 85 \\
\hline AMS & 60 & 85 & 76 \\
\hline NAKN & 40 & 51 & 61 \\
\hline $\mathrm{ND}$ & 42 & 67 & 66 \\
\hline $\mathrm{M}$ & 66 & 65 & 73 \\
\hline USI & 82 & 87 & 86 \\
\hline SRFP & 60 & 60 & 68 \\
\hline ET & 48 & 64 & 68 \\
\hline YS & 66 & 70 & 76 \\
\hline PGS & 44 & 63 & 65 \\
\hline NLP & 64 & 68 & 75 \\
\hline EPS & 60 & 74 & 75 \\
\hline MRT & 54 & 67 & 74 \\
\hline YS & 56 & 61 & 69 \\
\hline YES & 50 & 65 & 70 \\
\hline PDSM & 60 & 75 & 76 \\
\hline RYS & 66 & 72 & 78 \\
\hline FS & 58 & 63 & 73 \\
\hline ASD & 60 & 74 & 75 \\
\hline NMA & 66 & 78 & 80 \\
\hline MS & 50 & 52 & 67 \\
\hline MYS & 60 & 85 & 76 \\
\hline MS & 48 & 62 & 67 \\
\hline RYS & 48 & 48 & 68 \\
\hline ALH & 58 & 67 & 72 \\
\hline SMH & 60 & 62 & 71 \\
\hline DWS & 48 & 67 & 68 \\
\hline WCN & 50 & 69 & 69 \\
\hline TOTAL & 1966 & 2325 & 2465 \\
\hline Average & 57.82 & 68.38 & 72.00 \\
\hline
\end{tabular}


The data can be concluded that there is difference in students' listening skill after introducing the new vocabulary in each cycle. In pre cycle the mean is $57.82 \%$. The students had difficulties in comprehending the audio that spoken by native speakers. They did not know what they heard.In cycle one, after the researcher introduced the vocabulary for the first time the results of students' writing were improved. Students understand the meaning what they heard from form the audio better. In this cycle, the mean score was increased to $68.38 \%$. This shows that there is improvement in students' listening. Introducing the new vocabulary and the sound were good in helping the students to comprehend the listening content of audio But it is still needed improved to get higher score. So, the research was continued to the cycle II.

In cycle two students were assigned to pronounce the new words to improve listening comprehension. So the problems faced in the previous cycle can be solved. In this cycle the content and organization item of students' listening were significantly improved. The mean score is 72.00. From the explanations above, the researcher concludes that the implementation of introducing new word before listening the audio can improve students' activities in learning process. It can be seen from the result of the observation checklist that was summed up on the table below:

Table 3 Students' Activities

\begin{tabular}{|c|r|r|l|}
\hline Activities & Pre cycle & Cycle 1 & Cycle 2 \\
\hline Percentage & $69.01 \%$ & $74.54 \%$ & $85.45 \%$ \\
\hline
\end{tabular}

Pre cycle activities have percentage $69.01 \%$. It means that the activity of pre cycle was average. The percentage of students' activities when the researcher implemented introducing the new words in cycle one, there is $74.54 \%$. In the second cycle is $85.45 \%$ in cycle three. It is excellent. It shows that there were improvements of students' activities, they were more active and be able to answer the questions. To give easier understanding about the result of this research, the result of test and observation checklist in every cycle can be showed of the chart bellows:

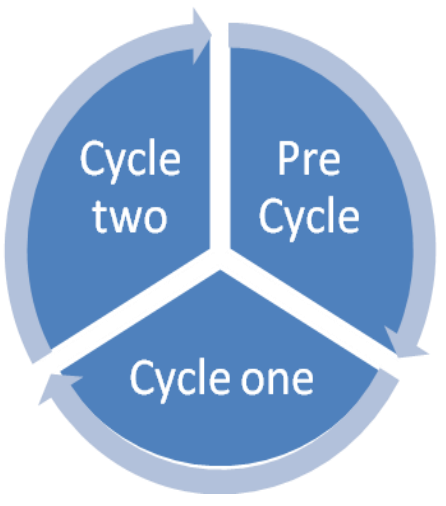




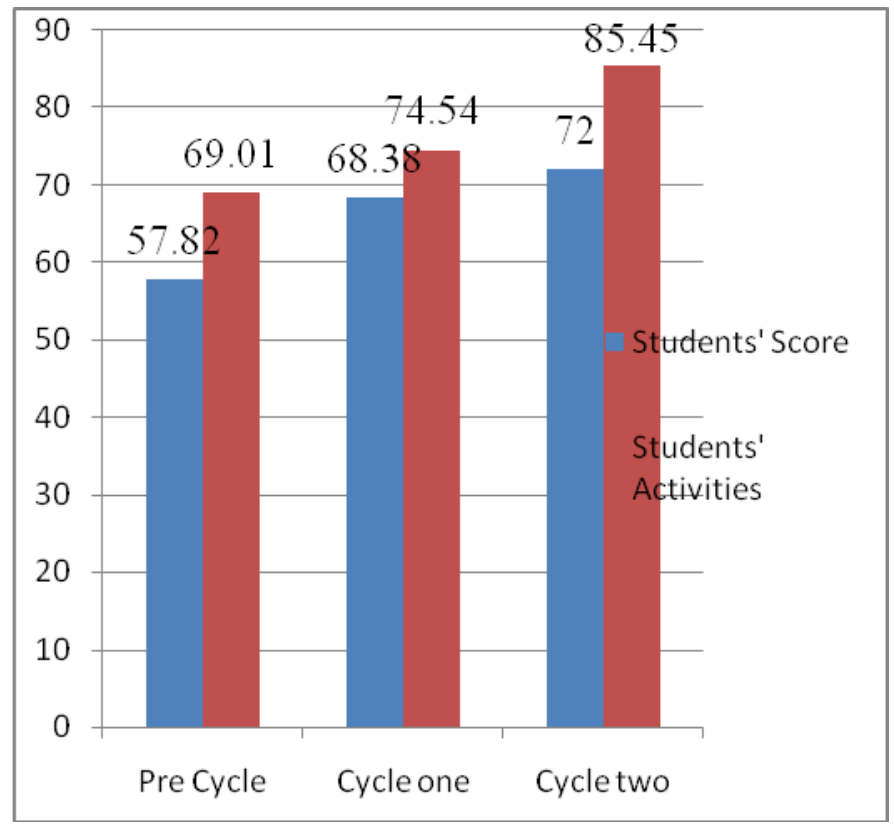

Figure 1. Cycle of Students’ Improvement Listening Comprehension

\section{Conclusion}

In this chapter, the researcher would like to draw some conclusions of the previous chapter, after conducting the researcher through observation and test. The researcher comes to some conclusion.

1. The use introducing new vocabulary has been advocated in teaching listening process. Typically, they are very interested to be implemented to improve listening skill. Students get easier listening process. However, the students can understand the material of listening comprehension in the classroom, be able to answer the questions.

2. The researcher found that the average score of the test in the pre cycle is 57.82 . The cycle I is 68.38 and cycle II is 72 . It means that there is always improvement in every cycle. The improvement of students' test score also indicates the student's listening comprehension is improving in every cycle.

From the result of observation shows that student's participation in the pre cycle is $69.01 \%$, cycle I is $74.54 \%$ and cycle is $85.45 \%$. Its means introducing the vocabularies improving students' listening skill can make students more active, motivates, and interested about the material.

\section{References}

Bell, J.( 2005). Doing Your Research Project 4th edition.New York: Open University Press.

Boulos, M.N.K., Maramba, I. \& Wheeler, S. (2006). A new Generation of Web

Brown, H.D. (2000).Principle of Language Learning and Teaching. San Francisco: San Francisco University. . (2004). Language Assessment: Principles and Classroom Practices. San Francisco: San Francisco University. . (2007). Teaching by Principles: An Interactive Approach to Language Pedagogy (Third edition). San Francisco: San FranciscoUniversity. 
Burns, A.(1999). Collaborative Action Research for English Language Teachers. United Kingdom: Cambridge University Press.

. (2010). Doing Action Research in English Language Teaching: A Guide for Practitioners. New York: Roudledge Taylor and FrancisGroup.

Dunn, L. (2002). Learning and Teaching Briefing Papers Series: Theories of Learning.Oxford Centre for Staff and Learning Development OCSLD.June 27, p. 99/ col. 2.

Feez, S., \& Joyce, H. (1998).Text-Based Syllabus Design.Sydney: ResearchMacquiarie University.

Grasha, A.F. (2002).Teaching with Style: A Practical Guide to Enhancing Learning by Understanding Teaching and Learning Style. San Bernadino:Alliance Publisher.

Helgesen, M. (2003). Listening in Practical Language Teaching.Edited by David Nunan.New York: McGraw-Hill.

Maria, A.S. (1998). Modules for the Professional Preparation of Teaching Assistants in Foreign Languages. Washington, DC: Center for AppliedLinguistics.

Stevens,V, \&Dieu, B. (2007). Pedagogical affordances of syndication, aggregation, and mash-up of content published on the Web. TESL-EJ,11(1).(http://teslej.org/ej41/int.html)

Syakur, A. (2020). Needs Analysis English For Specific Purposes (ESP) For Vocational Pharmacy Students, Budapest International Research in Linguistics and Education Sciences (BirLE). P. 724-73.

Vandergrift, L. (2006). Second Language Listening: Ability or Language

Proficiency?The Modern Language Journal 90, 6-18 